\title{
Galen and the Last Days of Commodus
}

\author{
Matthew Nicholls
}

Posterity's impression of the emperor Commodus has been almost universally negative. From Herodian and Dio to the lurid accounts in the 4 th C Historia Augusta, to Machiavelli and the modern age, he is decried as a monstrous tyrant, enslaved to his own ungovernable passions and an enemy to all virtue. ${ }^{1}$

The chief literary sources for Commodus' reign are not without their limitations. Dio, Herodian, and the Historia Augusta present accounts that are partially transmitted and/or highly dramatised, and veer towards cliché; each later account seems to build to some extent directly on its predecessor(s), limiting their collective usefulness as independent testimony.

Cassius Dio was, like Galen, a Greek contemporary of Commodus, well placed as a senator to observe his reign at close quarters. However, the part of his history which covers the reign of Commodus survives only in the 11th century summary of Iohannes Xiphilinus. What remains conveys an unremittingly critical, if somewhat scattered, impression of Commodus; Dio's loathing for the emperor is self-evident and is often attributed to his concern for the erosion of the senate's prestige and dignity (including his own experience of Commodus' dangerous and humiliating reign), and the personal fates of many of his senatorial peers. This may well be so, though it is worth remembering also that Dio's work, like Tacitus' a century earlier, was written under a new regime with an interest in portraying the rule of its predecessor, from whose violent downfall it had profited, as a period of disharmonious tyranny. There is also an element of historiographical convention in the work of a Dio or an Herodian; the age of Tacitus and Pliny had established senatorial utility and liberty as one important standard by which an historian might judge a reign, and write about it (Suetonius added other criteria including building works which, as we will see, also play a part in accounts of Commodus).

Herodian, a slightly later contemporary, characterises Commodus as a tyrant whose youthful elevation to power as the first emperor born 'in the purple' to a reigning father set an unhappy pattern for the child-emperors Herodian saw in the third century. The reliability of Herodian's account is also questionable;

1 Herodian 1.48; Dio 73.1.1, 73.4.1; SHA Comm. passim and esp. 1.7-8.

(C) MATTHEW NICHOLLS, $2019 \mid$ DOI:10.1163/9789004383302_012

This is an open access chapter distributed under the terms of the prevailing CC-BY-NC-ND License at the time of publication. 
he is obviously hostile to Commodus, portraying him as an archetypal bad, autocratic emperor, and his account is highly dramatised. ${ }^{2}$

The pro-senatorial agenda evident in Dio - or the emphasis of an anti-senatorial stance as a short-hand for tyranny - is amplified in the Vita Commodi of the Historia Augusta, a late 4th C AD set of imperial biographies whose unreliability is so infamous that there is little need to rehearse it here, but whose accounts of otherwise scarcely documented reigns nonetheless draw reluctant historians like moths to a flame. The HA's Commodus is a one-dimensional monster, a conflation of every bad-emperor trope. He is personally venal, susceptible to bad advisers, jealous of virtue, hostile to the entire senatorial order, in love with arena sports and harlots, given to driving chariots, and flirts outrageously with the idea of his own divinity: "saevior Domitiano, impurior Nerone. ${ }^{3}$ After a while the accounts of his turpitude start to sound hollow as the $H A$ author casts around for ever stranger proofs of his wickedness ("He displayed two misshapen hunchbacks on a silver platter after smearing them with mustard");4 the only remotely positive characteristic attributed to him in the entire Life is an ability to dance and whistle, which is then condemned as unbecoming to an emperor. ${ }^{5}$

There is, then, much to suspect in the literary record. It reads at points like an aggregation of clichés; it is evidently shaped by its authors' own agendas and is, especially in the case of the earlier two writers, the product of an age which had various types of interest vested in looking back critically at the end of the Antonine dynasty.

An account of the period from a well-placed contemporary, with interests that were not necessarily the same as those of Dio's senatorial order, would therefore be valuable. Galen's $\pi \varepsilon p i$ à $\lambda v \pi i a \varsigma$ (or 'On Avoidance of Grief'; henceforward $P A$ or in references 'Ind.', as elsewhere in this volume, for the Latin title De Indolentia) provides such a source, and though the direct testimony it offers is limited, it does offer contemporary witness to events at Rome in the last year of Commodus, and something of an immediate initial judgement on his reign. It is not an entirely disinterested account: Galen was, or had been, a member of the Antonine court, and I will suggest that his comments are probably intended

2 Hekster, O. (2002). Commodus: An Emperor at the Crossroads, 6; Kolb, F. (1972). Literarische Beziehungen zwischen Cassius Dio, Herodian, under der Historia Augusta, 160-1; Alföldy, G. (1971) 'Bellum Desertorum', Bonner Jahrbuch 171 (1971), 367-76.

3 "More savage than Domitian, fouler than Nero": SHA Comm. 19. All translations from Greek and Latin are by the author.

4 SHA Comm. 11.

5 SHA Comm. 1, which also says that he was able to fashion goblets and "play the gladiator or jester". 
to be in some sense self-exculpatory. However, since Galen is emphatically not writing, like Dio, with the benefit of longer hindsight, or from the perspective and with the agenda of a senatorial historian, and unlike our other sources has the dubious benefit of having experienced Commodus' reign at first hand, the $P A$ does, I think, offer useful new insight into this period. ${ }^{6}$

Firstly, we can be confident that the $P A$ was written very shortly after the events it describes, and is therefore considerably earlier than any other surviving testimony. This does not in itself guarantee a superior insight into Commodus' reign: events were still unfolding, and Galen is cautious rather than explicit in his account, not wanting to risk leaving himself exposed. On the other hand, the negative verdict of posterity on Commodus had not yet had time to crystallise, lending extra weight to this early testimony.

The date of the $P A$ is reasonably well established. The text principally concerns the fire at Rome in AD 192, the year on whose last day Commodus was assassinated. Galen discusses the fire as a very recent event. It had happened, he writes, "at the end of winter" and "two months" before Galen had intended to move some of his lost books to Campania "at the beginning of summer" (Ind. 23a, 20), so a date in the late winter or early spring of 192 seems right. However, later on the $P A$ implies that Commodus is no longer emperor (Ind. $54-5$, discussed below, whose criticisms of Commodus would have been fatally indiscrete were he still alive and in power), ${ }^{7}$ which implies that Galen is writing perhaps a year or so after the fire, some time in 193. This interval of time fits with other details in the text: Galen tells us that he has returned to Rome from Campania after the fire; also, since news of the fire has reached his anonymous correspondent via a messenger, and a letter from him has come back to Galen, to which the $P A$ is ostensibly a reply (Ind. 1-3), we also have to allow time for this epistolary exchange to have taken place. ${ }^{8}$

Secondly, Galen's propinquity to the Antonine court adds to the importance of his account. He knew Commodus (from well before his principate) and his father personally; his service as an imperial physician brought him at times into unusual intimacy with the most powerful people in the empire, and he must have been able to observe elements of court life at close hand. His return to Italy and then to Rome was precipitated by an imperial summons to military service in Aquileia and the flight of the imperial court back to Rome after an

6 As e.g. Boudon-Millot notes: "pour les historiens, ce nouveau témoinage est important. C'est le réquisitoire le plus ancien qu'on possède contre la tyrannie de Commode": Boudon-Millot, V. and Jouanna, J., with Pietrobelli, A. (2010). Galien. Ne pas se chagriner, 145.

7 cf. Rothschild, C. K. 'The Apocolocyntosis of Commodus' in ead. and Thompson, T. W. (2014). Galen's De Indolentia, $175^{-202}$, at 176 n.7.

8 cf. Nutton, V. (2012). Ancient Medicine, 232. 
outbreak of plague. ${ }^{9}$ Galen won the confidence of Marcus Aurelius by treating him on campaign in Germany, ${ }^{10}$ making a substantial reputation for himself and becoming an imperial protégé. Released from further military service by Marcus Aurelius in 169, Galen returned to Rome and found there all he needed to embark upon a protracted period of research and writing. He looked after the young Commodus on his father Marcus Aurelius' orders and had earned praise from Annia Faustina for treating him for a fever while the emperor was away at war between AD 172 and $175 .{ }^{11}$ He was thus at pains, in happier times, to indicate his continuing relationship with the imperial house: one that was never wholly attractive to him, but which brought undeniable benefits of material comfort and professional prestige (one fruit of this relationship, for example, was that many of the works he wrote during this time were deposited in the imperial library of the Templum Pacis, surely a mark of favour). ${ }^{12}$

Galen is generally reticent on the subject of contemporary politics, whether through conviction, expediency, or the fact that his authorial interests lay elsewhere. ${ }^{13}$ However, the $P A$ is markedly more politically engaged. As Rothschild points out, it adds, though relatively short, three more references to Commodus to the previous total of six in Galen's entire extant corpus, three of which refer to the medical care of the young Commodus and only one of which seems to offer criticism of the adult emperor, for discarding valuable stores of theriac. ${ }^{14}$ The comments in the $P A$, by contrast, are all directly critical of Commodus' tyranny, as if the events of 192 had prompted Galen to a much more explicit political position than he had adopted hitherto. What we have, then, is a text by a well-placed insider, someone with personal knowledge of the late emperor, who was in or near Rome during the dynasty's dramatic last year and who felt

9 Galen Libr. Prop. 1.15, 2.18 (XIX.14 and XIX.17-18 K.); cf Nutton, V. (1973). 'The Chronology of Galen's Career', Classical Quarterly 23 no. 1, 158-71.

10 Galen Praen. 11 (Xıv.66o K.).

11 See below n.14.

12 Libr. Prop. 2.19 (XIX.19 K.). Cf the similar honouring of Josephus, who received Titus' autograph imprimatur for his work (Josephus Vit. 363): Eusebius Hist. eccl. 3.9.2, Jerome De vir. ill. 13.1.

13 For Galen's political comments elsewhere, see Hankinson, R. J. 'The Man and his work' in id. ed. (2008). The Cambridge Companion to Galen, 1-33.

14 Ant.XIV.65.3 K.; the other passages regarding Galen's medical care of the young Commodus are Praen. XIV.650K.; Praen. XIV.657 K.; Praen. XIV.661K.; Lib. Prop. XIX.18-19K. See also Nutton, V. (1979). Galen: On Prognosis, 218. Hipp Epid. xviı.150.7 K. is about the paternity of Commodus. cf. Rothschild Apocolocyntosis, 178 with n.20. There is also Galen's account of the ability of Perennis' slaves to resist torture, an episode which implies criticism of the regime's abuses. It is preserved in the Arabic epitome of the lost On Moral Character; see Hankinson 'The Man and His Work', 21. 
moved by the fall of Commodus to make relatively direct political remarks. What can this add to our understanding of the period?

The passages in which Galen directly refers to court life under Commodus in the $P A$ come in a cluster in paragraphs $49,50 a$ and $54-55$, just over half way into the text. Paragraph 49 is a straightforward testimony to Galen's unwilling participation in the life of the Antonine court:

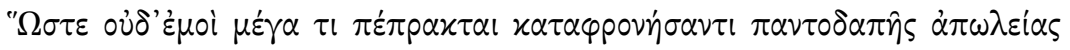

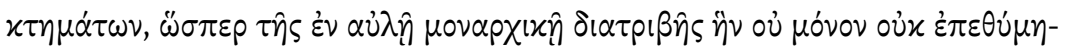

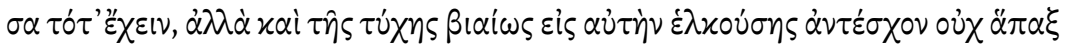

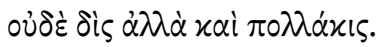

It was no great matter for me to scorn the loss of all my possessions, as I scorned also my time in the imperial court, which I not only did not want, but when Fate forcefully drew me towards it, I resisted not once, or twice, but many times.

Ind. $49^{15}$

This claim is particularly convenient to Galen in the aftermath of Commodus' downfall; he made it again in e.g. Libr. Prop. XIX.18 K. where the phrase $\dot{\xi} \xi$

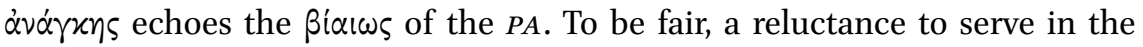
imperial court (at least an affected one) also colours other mentions of Galen's imperial connections. ${ }^{16}$

Galen's claim that he was a reluctant member of the court is amplified by the immediately following statement that he had many enemies there:

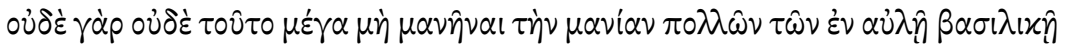

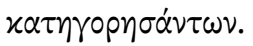

It was not even a great matter to avoid falling into madness despite the number of my accusers in the imperial court.

Ind. $5^{\circ}$

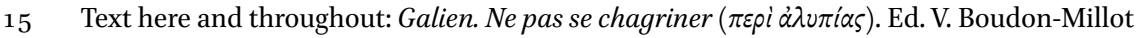
and J. Jouanna, with A. Pietrobelli. Paris: Les Belles Lettres, 2010.

16 See Boudon-Millot and Jouanna Galien, 132. cf n.9 above and Praen. XIv.647-9 K. with Gleason, M. 'Shock and Awe: the performance dimension of Galen's Anatomy Demonstrations' in Gill, C., Whitmarsh, T., and Wilkins, J. eds., Galen and the World of Knowledge, 2009, 85-114, for Galen's reluctance to have his successes brought to the attention of Marcus Aurelius, for fear that he would be summoned to return to Rome when his desire was to go home to Pergamum.
} 
This is not the only time that Galen mentions enemies and accusers, whether at court or elsewhere. ${ }^{17}$ The effect here is to show that not only was Galen reluctant to join the court, but also that he was not a popular member once there: he was not, then, a creature of the regime, but a reluctant outsider, resentful of the poisonous environment he had been drawn into and (it is implied) not complicit in the emperor's crimes.

With Galen's reluctant presence established in the reader's mind, there follows the $P A$ 's most explicit passage of criticism of Commodus:

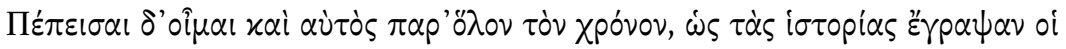

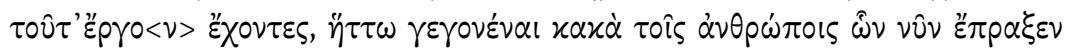

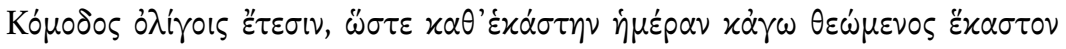

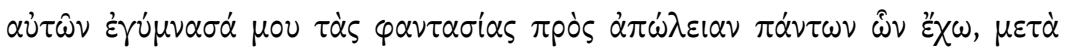

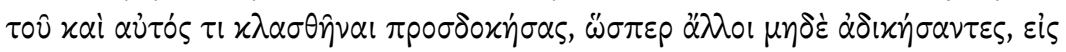

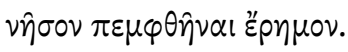

You are persuaded yourself, I believe, that in all of history, judging by the historical accounts written by those whose metier that is, fewer evils have befallen men than Commodus has recently committed in just a few years, such that I, who witnessed each of them daily, exercised my imagination against the loss of everything that I owned, expecting that I too would also be snapped off, so to speak, as had others who had done no wrong, and sent to a desert island.

Ind. $54-55$

Galen gives a damning verdict on the reign, and tells us that it is shared by his correspondent. The suggestion is that although Galen's position afforded a particularly close-up view of the horrors of Commodus' reign, they were by 192 generally known. There is a literary allusion in Galen's citation at Ind. $5^{2}$ of lines from an unknown play of Euripides in which Theseus undergoes similar mental preparations for possible adversities, including exile and untimely deaths, ${ }^{18}$ but it is the reference to previous writers of history that is particularly important here: Galen is claiming an acquaintance with historical writers and explicitly comparing (his account of) Commodus' reign to their historical accounts of other bad emperors. This is significant given the comparisons to

17 cf e.g. Praen. XIV.625 11-14 K. for accusations of $\varphi$ Өóvoৎ and criticisms from others at court; Libr. Propr. XIX.21 K. for numerous intellectual rivals at Rome.

18 See Kaufman, D. H., 'Galen on the Therapy of Distress and the Limits of Emotional Therapy', Oxford Studies in Ancient Philosophy 47, 2014, 275-296 (p. 281). 
Nero which we will consider below, and it also implies Galen's awareness that he is creating a historical testimony of a sort.

There is no reason to doubt the tenor of what Galen says here. The prospect of banishment and/or confiscation of goods was real enough under Commodus, in the unanimous testimony of our sources. Execution, whether summary or judicial, seems to have been more common, or at least more commonly reported by authors with no shortage of grim material to choose from, but both the punishments mentioned here by Galen are attested fairly often in the principal surviving accounts of the reign. ${ }^{19}$

Galen returns to the idea of banishment and confiscation again at Ind. 71:

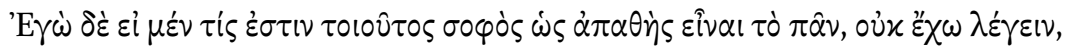

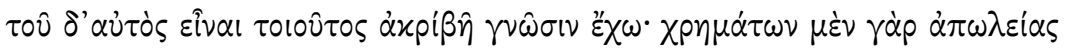

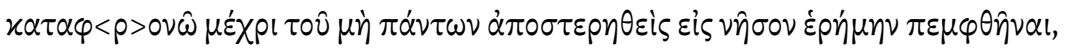

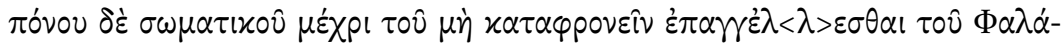

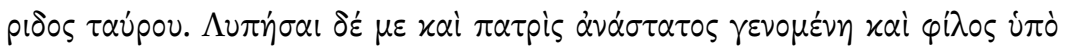

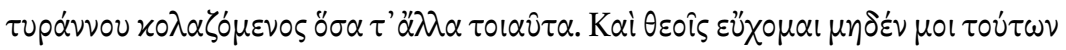

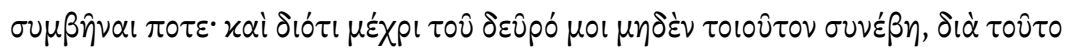

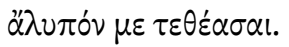

For my part, I cannot say whether there exists a man so wise that he is totally immune to suffering, but I have an accurate understanding of the sort of man I am: I can scorn the loss of money, until the point of being exiled to a desert island, deprived of everything, and physical suffering, until the point of declaring that I can hold the Bull of Phalaris in disdain. What will grieve me is my homeland ruined, a friend punished by a tyrant, and I pray the gods that none of these things will befall me. And since up until now none of those things has befallen me, you see me undistressed.

Ind. $71-72$

19 Instances of confiscation and exile/banishment:

SHA Comm.: 3.4 (actors), 4.4 (Paralius' mother and Lucilla); 4.11 (Aemilius Iuncus and Atilius Severus, the consuls); 5.7 (Commodus' sister, Lucilla, subsequently killed); 5.9 (his wife Crispina, subsequently killed); 5.13 (Perennis confiscates the wealth of provincials after false accusations); 6.9-10 (peculation of Cleander); 6.10 (recall of exiles at Cleander's whim); 7.8 (multiple murders for the sake of financial gain); 13.8 (ditto); 14.2 (ditto); 14.4 (substitution of punishments for financial gain).

Dio: 73.4.6 (Lucilla and Crispina); 73.6 (flight into presumed self-imposed exile of Sextus Condianus); 73.12.3 (a joking reference to Julius Solon's 'banishment' to the senate at the cost of all of his property).

Herodian: confiscation of property $(8.2,17.2)$, expulsion from the palace of men of intelligence (13.8). 
Here Galen locates his tolerance on a scale of suffering, from mere confiscation of assets (bearable) to desert island exile (not bearable), and from physical punishment to roasting alive in the legendary bronze bull of the Sicilian tyrant Phalaris. ${ }^{20}$ The reintroduction of the themes of confiscation and exile, heightened here by corporal and grotesque capital punishment, strengthens by repetition the criticisms of Commodus made in the earlier passages.

Galen also adds something new in this passage, taking the time to remind his correspondent and readership that his homeland, presumably Asia Minor, has not suffered ruin, and his own friends have not been exiled. This small addition, seeming almost an aside, serves several purposes. It sets up a preemptive defence against accusations of betrayal from contacts at home in Pergamum, and it also helps deflect any charge that Galen should have spoken out: not only was he afraid for his own safety, but (and one must admit the rather thin moral grounds of this argument) his own friends and countrymen were not in danger. Moreover, it would insulate him against association with those punished by the regime, should a pro-Commodus faction come to power looking for revenge. Granted, Commodus was a tyrant; but, as his death eventually showed, he was right to suspect plots against him, ${ }^{21}$ and Galen is keen to let us know that he was not associated with those who were punished by Commodus, whether deservedly or not. Given the uncertainty still in air when Galen was writing, as discussed below, this series of statements adds up to a calculated declaration of almost complete neutrality in Commodus' court: he didn't want to be there, he was not party to any crimes, he feared for his own safety, he was not friends with anyone who was punished, he did not stand idly by while anyone or anywhere close to him suffered.

Galen's testimony, short as it is, is that of an eyewitness and is the closest in date to the reign of any of our sources. It is undoubtedly valuable, but our reading of it must be tempered, as we have started to see, by an understanding of its limitations and context. We must first acknowledge that the new historical testimony offered by the passages of the $P A$ discussed above, though an important early witness to Commodus' brutality, is not particularly extensive or dramatic. ${ }^{22}$ Moreover, for all the relatively apolitical status he tries hard to

20 Cicero Verr. 4.73; Diodorus Siculus 9.19.1. cf. Rothschild 'Apocolocyntosis', 185-87, which suggests that the connection in AD 192/3 of a tyrannical ruler with a bull would have brought to mind Commodus (as Hercules). when they discovered a conspiracy, no one believed them unless they had been killed."

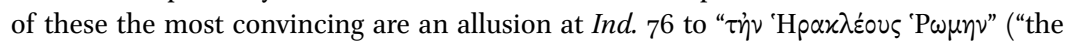
strength $(\dot{\rho} \omega \dot{\mu})$ ) of Heracles", but a play on Commodus' megalomaniac association with 
establish, Galen cannot be thought of as a disinterested observer. His proximity to the discredited regime, a useful professional connection during the reigns of the Antonines, could have become dangerous for him in the aftermath of Commodus' fall. We have already begun to read the $P A$ as an initial attempt to outline a defence against the multitude of intellectual and perhaps political enemies who often lurk at the margins of Galen's accounts of himself, or the accusations of whatever faction would eventually come to power: ${ }^{23}$ his case here is that he had, like a Tacitus or a Pliny, been an unhappy bystander in a tyrant's court, and was now finally in a position to reveal Commodus' guilt, and his own innocence. In such a context, the brevity of these remarks compared to Galen's overall silence on politics might itself be eloquent, a claim to be absorbed in the life of letters that occupies much of the first part of the $P A$, rather than caught up in the extraordinary political dramas that were playing out in the year that Rome burned: dynasties might fall and rise, and the city is in ashes, but Galen presents himself as barely a participant, bookishly concerned instead with the loss of his glossaries of Attic old comedy and prose. ${ }^{24}$

Moreover, we might reasonably believe that Galen is hedging his bets. His distancing of himself from Commodus is cautious, and incidental to the purported substance of the $P A$. He was writing at an uncertain moment. Commodus was dead, but the next emperors Pertinax and Didius Julianus would follow him within a matter of months, with three more claimants still in play. It was not until 197 that Septimius Severus finally saw off the challenges to his reign. It is not surprising, then, if Galen, writing when the final outcome of the 'year of the five emperors' was far from clear, used the $P A$ to put some distance between himself and Commodus without committing himself too far. Historical verdicts on emperors' reigns took some time to settle down, even if they came in hindsight to look immutable. The tussle over Nero's reputation in 68-9 and afterwards, with the emergence of false Neros as late as the reign of Domitian, ${ }^{25}$ is an obvious case in point. There is some suggestion that an alternative historiographical tradition retained a measure of praise for Commodus, indicating that his negative reputation was not immediately established and may not (as with Nero) have been universally shared. ${ }^{26}$ Hekster suggests that Commodus

Hercules and his attempts to refound Rome ('P' $\omega \mu \eta)$ in his own image), and at Ind. 62 a suggestion of Rome's (or Commodus') moral decline through sexual incontinence in the metaphor of breeding birds rented out to stud.

See Ind. 5oa and n.17 above for enemies explicitly in the court and elsewhere

24 Ind. 20.

25 Suet. Nero 57.

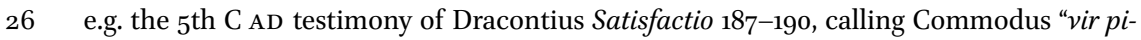
etate boni" (perhaps echoing the Pius legend added to his coinage from AD 182-3: Hekster 
retained a greater measure of popularity among the army and in the provinces than with the later authors who shape our view. ${ }^{27}$ Galen's anonymous correspondent, and his initial intended audience, may have been at home in Asia Minor, and we have seen that Galen takes care to point out that this homeland did not suffer: perhaps this was a nod to a sceptical provincial audience.

We must also, of course, remember that Septimius Severus, into whose service Galen passed, ${ }^{28}$ reversed the senate's damnatio memoriae of Commodus, promulgated his deification, renamed his son Caracalla as Marcus Aurelius Antoninus, and included Divi Commodi Frater in his own titulature. ${ }^{29}$ Evidently Septimius Severus prized an adoptive association with the Antonines, including their last emperor, above any negative memories of Commodus' recent reign. He also, of course, continued to claim a very strong association with Commodus' patron deity Hercules. ${ }^{30}$

There was still an audience, then, to whom the memory of Commodus was not entirely toxic in the 190 and the 200s; the Senate were clearly hostile to his memory, but Severus had other constituencies to consider. In this context Galen's restraint in his criticism of Commodus proved to have been wisely judged, allowing him to escape any fatal recrimination in the immediate aftermath of Commodus' fall, and to remain in imperial service once the new Severan regime (if not senatorial opinion, or the overall judgement of posterity) had decided that Commodus' reputation was to be rehabilitated for political reasons of its own.

With all these caveats in mind, the fact remains that the $P A$ is far more politically engaged than the rest of Galen's work, strongly suggesting that part of its purpose was to place on record (muted, cautious) criticism of Commodus' reign. ${ }^{31}$ Galen is protecting himself, distancing himself from a regime he had

Commodus p. 92 for coin legend date). Although no modern author seeks to rehabilitate Commodus entirely, recent scholarship has tried to achieve a more balanced view. Olivier Hekster's Commodus applies a careful attention to image-making and self-presentation, reading the ideological implications of Commodus' Bildprogramm as expressed in visual media like coinage, architecture, sculpture, and spectacle. He finds some echoes of Commodus' self-presentation in contemporary art.

27 Hekster Commodus, 201.

28 Galen XIV.217f K.; Birley, A. (1971). Septimius Severus, The African Emperor, $286-87$.

29 Dio 76.7.4; cf sha Sev. 10.6, 11.4; Aurelius Victor 20.30. Hekster Commodus, 189ff.

30 cf Jordanes Rom. 372, Malalas 12.1; 283 and the neutral description of Commodus' association with Hercules by Athenaeus, whose patron Larensis was that emperor's procurator patrimonii: Ath. 12.537ff. and Hekster Commodus, 184 n.116-7.

31 Which does not rule out other aims - a genuine essay in philosophical consolation, for example; an announcement to his friends and supporters that he was alive and undaunted after the fire; and a warning against purported copies of works now irredeemably lost: the 
every reason to have loathed but with which he was nonetheless associated; he was hedging because the position was still fluid and he knew he had enemies at court and elsewhere. For all these limitations - indeed, in a sense because of the fact that Galen is treading carefully, holding back - this immediate but carefully limited condemnation of the reign is a valuable addition to the historiographical record.

Galen was not the first author to wait until the fall of a regime to criticise it, and would not be the last: Tacitus earlier in the century, and Dio in the next, did the same. We have already seen that Galen was aware of historical and historiographical precedent. In Ind. 54 he compares Commodus' reign to what can be found in the accounts of historical writers and in doing so alludes to Commodus' place, and of his own brief account of it, in the historiographical record. With this in mind, I will spend the rest of this chapter looking at Galen's treatment of the fire of Rome in AD 192, which provides the backdrop for the whole of the $\pi \varepsilon p i \dot{\alpha} \lambda u \pi i a \varsigma$, and suggest that it may be intended to evoke earlier disasters in Rome and particularly to invite comparisons with Nero.

The fire of 192 seems to have come in a period of growing tension, when Commodus' divinising self-aggrandisement was already causing, or responding to, faltering popularity and the alienation of the senatorial order. A riot in 190 at the fall of Commodus' freedman and Praetorian commander Cleander, linked to rising grain prices, seems to have alarmed the emperor or caused a change of tactics in his self-presentation. ${ }^{32}$ His promotion of a 'Commodian' golden age and increasing self-presentation as Hercules had accelerated from around that time; Hercules-Commodus was celebrated in coin issues, going "well beyond what all but the most extravagant Roman emperors had put forward". 33

At this critical juncture came the fire of 192. There are several points of connection between the accounts offered by Galen and Dio, who were contemporaries and both in or near Rome at the time. Dio, a senator under Commodus, may have been an eyewitness; Galen was away in Campania, but clearly returned to Rome shortly afterwards. ${ }^{34}$ They may have had similar sources for their accounts of the fire and there is little reason to doubt the congruence in points of detail. For example, Dio (whose account of the fire is at 73.24) mentions dwelling houses as a starting point, and Galen stresses the understood

detail entered into suggests that Galen was trying to establish firmly what had been lost. He returns to his warning against plagiarized and fraudulent literary works in Lib. Propr., XIV.8-48 K.

32 Dio 73.13.1; Herodian 1.13.7; SHA Comm. 14.1-3, cf Dio 73.15.6.

33 Hekster Commodus, 103.

34 Ind. 11. 
risk of fire posed by proximity to dwelling houses (Ind. 8). The route of the fire and its path of destruction from the Templum Pacis across the Sacra Via to the Palatine is broadly similar in both authors (see map), and - the most telling point of detailed correspondence - both mention the destruction of state records, with Dio turning this loss into a portent of global misfortune. ${ }^{35}$ If Dio was right that this destruction had been seen at the time as a portent of a more universal turmoil, then by the time of Galen's writing the following year, after Commodus' fall, it might have begun to acquire an air of retrospective confirmation: although, as we have seen, Commodus is absent from the $P A$ until past the half-way point of the text, Galen flags up this ominous destruction of imperial records early on at Ind. 8.

Both authors, then, give the fire a similar treatment. It is not surprising that for Dio, writing with the benefit of hindsight, the fire acquired a teleological force, forming part of a crescendo of events that would sweep Commodus from power. He links the fire explicitly to the downfall of the emperor, placing it in a sentence that begins "before the death of Commodus the following portents occurred". ${ }^{36}$ In fact, his account of Commodus' reign and the entire (excerpted) book ends with a sentence ostensibly describing the fire but clearly referring also to the emperor's career and death: "But when it had destroyed everything which it had seized, it spent its force and died out". ${ }^{37}$ Herodian follows Dio in making it a portent of the end of the reign, with the blaze started either by a lightning bolt or an earthquake (either way, a sign of divine displeasure). ${ }^{38}$ It is not unreasonable to suggest that this view of the fire was available immediately to contemporaries, including Galen who was writing, we should remember, when the fallout of the events of 192 was still occurring: he might well have intended the $P A$ 's account of the fire to point towards the fall of the emperor at whom the same work direct unprecedented criticism.

Moreover, since it is also possible to observe deliberate echoes of the Neronian fire in Dio's treatment of the fire under Commodus, this trope - which

35 Dio 73.24.2 (the text throughout is Dio Cassius. Roman History. Ed. H. B. Foster. Cambridge,

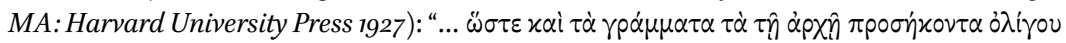

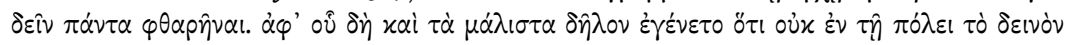

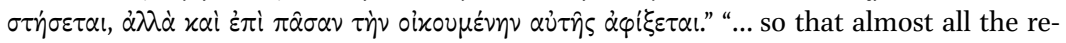
cords belonging to the state were destroyed. From this in particular it was clear that the evil would not stay within the city, but would spread to its whole empire." Galen Ind. 8:

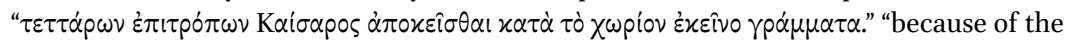
presence in that place [the burned storehouse] of the archives of four imperial procurators." Cf Herodian 1.14.6.

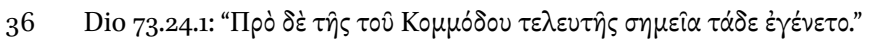

37 Dio 72.24.3: “ $\alpha \lambda \lambda^{\prime}$ '

38 Herodian 1.14.2. 
is, after all, a fairly obvious one - could also have been in Galen's mind as he described the devastation caused by the fire and more cautiously alluded to the tyrannical reign of the late emperor. We have already seen that Galen was able to connect Commodus' reign to the historiographical tradition of bad emperors. There was also a historiographical tradition of disaster-narrative, linking the ruination of cities across time both to make comparisons and to imply the cyclicality of human affairs. Thus Scipio wept for the future fall of Rome as he watched Carthage burn, ${ }^{39}$ while Tacitus' account of the Neronian fire of 64 explicitly connects it in the Roman imagination with the sack of the city by the Gauls 418 years previously, ${ }^{40}$ implying that disasters like the fire were understood through comparison to accounts of earlier catastrophes. In literary terms, the antecedents for Tacitus' fire narrative draw heavily on Livy's account of the Gallic sack and also on Virgil's account of the fall of Troy (while Scipio quoted Homer), depicting historical events through a series of literary references stretching all the way back to the founding story of Classical literature. ${ }^{41}$

Galen, and later Dio, placed their own accounts of the fire of 192 into this tradition. We would expect to find historiographical connections in the accounts left by the historians. We can certainly observe commonalities in Dio's and Tacitus' accounts; Dio explicitly follows Tacitus, for example, in claiming that as the Neronian fire advanced to consume the city as a whole, it was compared to national disasters like the Gallic sack ${ }^{42}$ Another theme shared by Tacitus and Dio's account of the earlier fire, which also emerges in Galen's account of the later one, is the self-defeating response of the overwhelmed citizens. Dio writes that "many, crazed by the disaster, were leaping into the flames".43 Tacitus similarly reports irresolute and ill-advised conduct during the fire, and claims that some were engulfed by despair afterwards: "some who had lost their entire fortunes - including their daily bread - and others, through love for the relatives whom they had been unable to rescue, chose to die, though an escape route was open". ${ }^{4}$ These reports of irrational, self-harming surrender to emotions of various sorts sound like the sort of conduct Galen warns against

39 Appian Bellum Punicum 19.132.

40 Tac. Ann. 15.41.

41 Livy 5.43-59 with Kraus, C., 'No second Troy: topoi and refoundation in Livy Book V', Transactions of the American Philological Association 124, 1994, 267-89 and Champlin, E. T., Nero, 2003, 178-209. For Tacitus and Virgil: Feeney, D., Caesar's Calendar: Ancient Time and the Beginnings of History, 2007, 107. Cf. Edwards, C. 'The City in Ruins' in Erdkamp, P., ed., The Cambridge Companion to Ancient Rome, 2013, 549-557.

42 Dio 62.17.3.

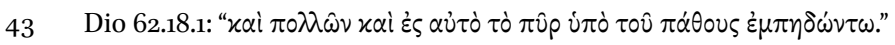

44 Tac. Ann. 15.38: "quidam amissis omnibus fortunis, diurni quoque victus, alii caritate suorum, quos eripere nequiverant, quamvis patente effugio interiere." 
in the $P A$. In particular, the $P A$ 's account of Galen's own exemplary resistance to grief in the aftermath of the fire, placed in contrast with the conduct of the grammarian 'Philides' and unnamed others who suffered grief at their losses to the point of mourning or even death ${ }^{45}$ may itself have been patterned after these historical accounts of similar self-destructive grief of Romans and others after earlier disasters, and in particular the fire of $\mathrm{AD} 64$, as well as by the parallel tradition of evoking city-ruins in consolation. ${ }^{46}$

Galen and Dio may therefore have had accounts of Nero's fire in mind when they wrote of the fire under Commodus. The parallels between Commodus' and Nero's involvement in and response to fires at Rome, and the ways in which Dio and (for Nero) earlier writers portrayed them, are therefore worth exploring.

Firstly, and most obviously, the Neronian fire of Rome in 64 seems to have been viewed in retrospect as one of the turning points in Nero's reign, just as we have seen for the fire of AD 192. Suetonius places the fire at the end of his account of Nero in a list of "disaster and abuses" which herald his downfall; 47 Tacitus includes it in a year which ends with "portents heralding disaster to come" and moves straight into the Pisonian conspiracy of $65 .{ }^{48}$ Dio, who blames the fire squarely on Nero himself, gives some space to Corbulo's successful exploits in Armenia in the sort of chiaroscuro alternation that Tacitus also enjoyed, and then moves on to the conspiracy against Nero, whose repression marked a new low in the reign..$^{49}$

The conduct attributed to each emperor during and after the fires was similar. Both were outside Rome when it broke and out, and both came into take (fairly ineffectual) measures against it. Nero, according to Tacitus, was staying at Antium and only returned to Rome when his Domus Transitoria was threatened. He then opened up the Campus Martius, the buildings of Agrippa, and his own Gardens to homeless refugees from the fire, and built shelters for them. ${ }^{50}$ Though traces of a practical and humane response are evident in Suetonius and Tacitus' account, the fire is explicitly attributed to Nero (Suetonius Nero 38, Dio 62.16.2) or linked to his agency by strong and undenied rumour (Tacitus

\footnotetext{
$45 \quad$ Ind. 7 .

46 E.g. Cicero Fam. 4.5.4 for Servius Sulpicius Rufus' famous evocation of the ruins of Aegina, Megara, Piraeus and Corinth to console Cicero on the death of his daughter Tullia.

47 Suet. Nero $38-9$.

48 Fire: Tac. Ann. 15.38-44; portents ("fine anni vulgantur prodigia, inminentium malorum nuntia") listed at $47-8$.

49 Fire: Dio 62.16-18. Corbulo and Armenia: 62.19-23. Plot against Nero and its repression: $62.24-28$.

50 Tac. Ann. $15 \cdot 39$.
} 
Ann. 15.38). Commodus, according to Dio, also travelled into Rome, from the suburbs, and encouraged ineffective military and civilian measures to extinguish the blaze..$^{51}$

A more substantial correspondence between the emperors is found in their conduct after the fire. The reason for Nero's alleged culpability for the fire lay in his megalomaniac building ambitions, while Commodus' actions around the time of the fire and in the aftermath show similar vainglorious tendencies. Commodus is only blamed for the fire by the unreliable Historia Augusta ("He ordered the burning of the city, as if it were his private colony"), ${ }^{52}$ but while we have no reason to believe this, the obvious patterning of the accusation after accounts of Nero's arsonism is illuminating in this context: while not explicitly blaming Commodus for the fire of 192, the more reputable sources do agree that both emperors allegedly wanted to rebuild Rome in their own image, renaming it and refashioning it to suit their own ends.

The evidence for Nero's architectural ambition and actual achievements is plentiful; multiple literary testimonies, the renaissance rediscovery of the Golden House, and more recent archaeological work shows a huge construction effort which reshaped parts of the Palatine, Esquiline, and Caelian hills and the low ground between them, where the Colosseum now sits, and the equally rapid effacement of these projects in the succeeding reigns. ${ }^{53}$ The evidence for Commodus' ambitions, both literary and archaeological, is more slender, but the point here is that the way Dio, the SHA, and perhaps Galen viewed and wrote about the fire in his reign was shaped by the way that they and others had viewed Nero's.

For Tacitus, who professes to be uncertain on the question of whether Nero actually started the fire, "it seemed that Nero was seeking the glory of founding a new city and calling it by his own name". ${ }^{44}$ The emperor "made use of the destruction of his fatherland by building a palace", which Tacitus called "hated and built of the spoils taken from citizens". ${ }^{55}$ Particularly objectionable was

$51 \quad$ Dio $73.24 \cdot 3$.

$52 \quad$ SHA Comm. 15.7: "urbem incendi iusserat, utpote coloniam suam."

53 Domus Aurea: Suet. Nero 31, 39; Pliny NH 33.54, 36.111; Martial Spect. 2; Tacitus Ann.15.42. Champlin, Nero, 178-209. For the archaeology, see e.g. Steinby, E. M. ed., Lexicon Topographicum Urbis Romae, Vol. II, 1995, 49-64; Panella, C. et al. Meta Sudans I: un area sacra in Palatio e la valle del Colosseo prima e dopo Nerone, 1996.

54 Tac. Ann. 15.40: "videbaturque Nero condendae urbis novae et cognomento suo appellandae gloriam quaerere."

55 Tac Ann. 15.42 ("Nero usus est patriae ruinis exstruxitque domum"), 15.52 ("in illa invisa et spoliis civium extructa domo"). Ann. 14.53 (cf Suet. Nero 16) does in fairness list a series of impressive and practical rebuilding measures taken by Nero after the fire with a view to preventing a recurrence, including regulations on building heights and materials and the 
the Colossus, an enormous (12oft) bronze statue of Nero in the palace vestibule which - too impressive to go to waste after Nero's fall - was later remodelled as the sun god Helios, becoming the eponym of the nearby Colosseum. ${ }^{56}$

Nero's ambitions extended beyond the palace and over the entire city, which the palace was rapidly swallowing up, as the famous pasquinade related by Suetonius complains. ${ }^{57}$ Suetonius claims that he wanted to rename the city Neropolis, deftly signaling both the emperor's megalomania and his unseemly philhellenism; the same passage reports that the emperor also wanted to rename the month of April 'Neroneus.'58 Tacitus also reports the emperor's purported ambition to rename Rome after himself, linking it to his widely believed responsibility for the fire. ${ }^{59}$

We can now turn to what Dio tells us about Commodus' conduct around the time of the fire of 192. He posed as the founder of a renascent Rome, to be renamed after himself: Colonia Antoniniana Commodiana. ${ }^{60}$ The Colossus near the Colosseum was, according to Dio, remodelled in his likeness, its head replaced with Commodus', a lion skin and club added to evoke his patron deity, and a bathetic list of the gladiator-emperor's arena victories added to the base. ${ }^{61}$ Commodus' onomastic vainglory extended to the months of the year, all twelve of which he intended to name after himself. ${ }^{62}$

This sequence, linking fire and megalomaniac rebuilding with the renaming of the months and the remodelling of the Colossus, sounds suspiciously familiar: Dio surely has Nero in mind. His portrayal of the stagey, degenerate emperor whose reign ended in a conflagration naturally looked back to his and others' accounts of Nero, adding or emphasising those elements - renaming the city and the months, representing himself in the giant Colossus - that would remind his readers of that proverbially disastrous reign. A sense of crisis mounts as the emperor's deeds and ambitions spiral out of any semblance of

provision of fire-fighting equipment, but only after strongly implying Nero's involvement in firing the city for his own gain, and mentioning the Gallic sack again.

56 Suet. Nero 31, Pliny $N H$ 34.45, Dio 65.15. For the remodelling, Pliny loc. cit., Suet. Vesp. 18, Martial I.70.7 and Spect. 2.1.

57 "The whole of Rome's becoming a single house! Move to Veii, citizens, unless that house doesn't spread to Veii as well". Suet. Nero 39 .

58 Suet. Nero 55 .

59 Tac. Ann. 15.40.

6o Dio 73.15.2; cf shA Com. 8.6-9, 15.7. RIC 3, 247, 629 .

61 Dio 73.22.3, SHA Com. 17.9-10; Herodian 1.15.9; Hekster Commodus, 123-4; Bergman, M., Der Koloß Neros, die Domus Aurea und der Mentalitätswandel im Rom der frühen Kaiserzeit, 1994, 12. For Nero's own disreputable career as a performer and its pseudo-triumphal commemoration in Rome, see e.g. Suet. Nero 1-14, 20-25.

Dio 73.15.3-4; Herodian 1.14.9. 
rational control, and the fire is used as the final point of correspondence with Nero, and the harbinger of Commodus' downfall.

Galen, though not a historian and writing much closer in time to these events, uncertain of their final outcome, was nonetheless able to see Commodus' reign in both a historical and a historiographical context. He seems to have been aware of previous accounts of bad emperors, and of the way previous urban catastrophes at Rome had been written about and linked to these reigns. Connections between Galen's treatment of Commodus' reign and the fire and those of later authors suggest a degree of similarity in their respective approaches. The comparison with Nero, which is so strongly evident in Dio's account, would have been available to Galen as well, and earlier accounts of Nero's fire may have shaped his thinking and writing in the immediate aftermath of Commodus' downfall. In the context of what is by far the most politicised treatment of Commodus that Galen gives us, these connections help show us how immediate contemporaries thought about the terrible events of 192, and point the way forward to what would become the conventional historiographical verdict on Commodus and his reign.

\section{References}

Alföldy, G. 'Bellum Desertorum.' Bonner Jahrbuch, 171 (1971): 367-76.

Bergman, M. Der Koloß Neros, die Domus Aurea und der Mentalitätswandel im Rom der frühen Kaiserzeit. Mainz: Trierer Winckelmannprogramm, 1994.

Birley, A. Septimius Severus, The African Emperor. London: Eyre and Spottiswoode, 1971. Champlin, E. T. Nero. Cambridge, Mass and London: Harvard, 2003

Edwards, C. 'The City in Ruins' in The Cambridge Companion to Ancient Rome, ed. Erdkamp, P., 541-57. Cambridge, 2013.

Feeney, D. Caesar's Calendar: Ancient Time and the Beginnings of History. Berkeley: University of California Press, 2007.

Gleason, M. 'Shock and Awe: the performance dimension of Galen's Anatomy Demonstrations' in Galen and the World of Knowledge, edd. Gill, C., Whitmarsh, T., and Wilkins, J., 85-114. Cambridge: 2009.

Hankinson, R. J. 'The Man and his work' in The Cambridge Companion to Galen, ed. id. 1-33. Cambridge: 2008.

Hekster, O. Commodus: An Emperor at the Crossroads. Amsterdam: J. C. Gieben, 2002.

Kaufman, D. H. 'Galen on the Therapy of Distress and the Limits of Emotional Therapy', Oxford Studies in Ancient Philosophy 47 (2014), 275-96.

Kolb, F. Literarische Beziehungen zwischen Cassius Dio, Herodian, under der Historia Augusta. Bonn: Antiquitas Reihe 4.9, 1972. 
Kraus, C. 'No second Troy: topoi and refoundation in Livy Book V', Transactions of the American Philological Association 124 (1994), 267-89.

Nutton, V. ‘The Chronology of Galen's Career', Classical Quarterly 23 no. 1, (1973): 158-71.

Nutton, V. Ancient Medicine. 2nd ed., London: Routledge, 2012.

Panella, C. (ed.). Meta Sudans I: un area sacra in Palatio e la valle del Colosseo prima e dopo Nerone. Rome: IPZS, 1996.

Rothschild, C. K. 'The Apocolocyntosis of Commodus' in Galen's De Indolentia, ed. ead. and T. W. Thompson, 175-202. Tübingen: Mohr Siebeck, Studien und Texte zu Antike und Christentum 88: 2014.

Steinby, E. M. (ed.). Lexicon Topographicum Urbis Romae, Vol. II, D-G. Rome: Edizioni Quasar, 1995 .

\section{Texts Used}

Dio Cassius. Roman History. Ed. H. B. Foster. Cambridge, MA: Harvard University Press 1927.

Historia Augusta, Commodus. Ed. D. Magie. Cambridge, MA: Harvard University Press, 1921.

Galien. Ne pas se chagriner ( $\pi \varepsilon p i \grave{\alpha} \lambda u \pi i \alpha \varsigma)$. Ed. V. Boudon-Millot and J. Jouanna, with A. Pietrobelli. Paris: Les Belles Lettres, 2010.

Tacitus. Annals. Ed. J. Jackson. Cambridge, MA: Harvard University Press, 1937. 